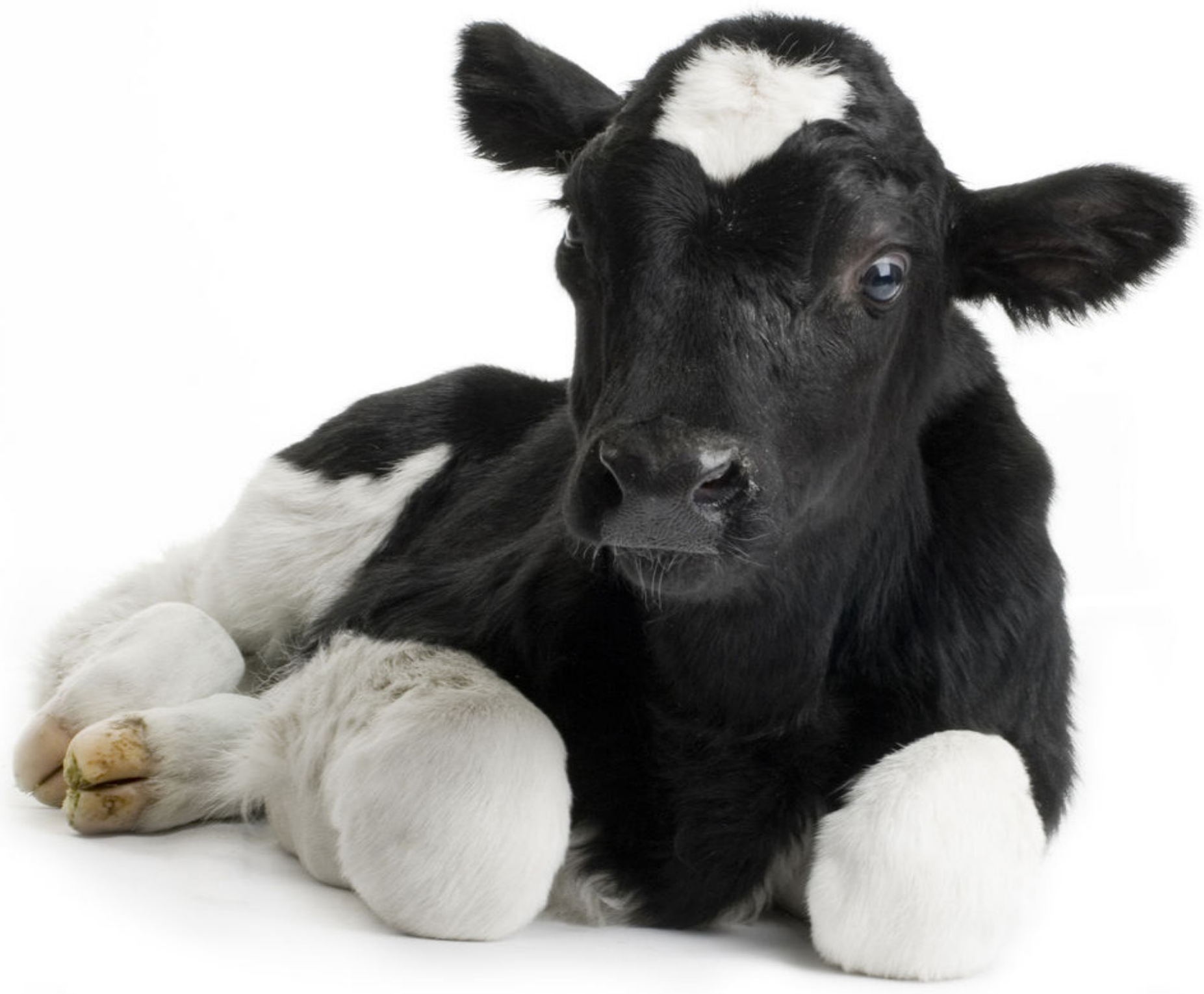

Kalverstal van de toekomst - (bijna) Praktijkrijpe ontwerpconcepten

D. Puente-Rodríguez, I.D.E. van Dixhoorn, F.A. Hoorweg, L.R. Gollenbeek, C.G. van Reenen, A.J.A. Aarnink, N. Verdoes en S. Bokma. 



\section{Kalverstal van de toekomst - (bijna) Praktijkrijpe ontwerpconcepten}

D. (Daniel) Puente-Rodríguez, I.D.E. (Ingrid) van Dixhoorn, F.A. (Fleur) Hoorweg, L.R. (Luuk) Gollenbeek, C.G. (Kees) van Reenen, A.J.A. (André) Aarnink, N. (Nico) Verdoes \& S. (Sjoerd) Bokma.

Wageningen Livestock Research

Dit onderzoek is uitgevoerd door Wageningen Livestock Research, in opdracht van en medegefinancierd door het Ministerie van Landbouw, Natuur en Voedselkwaliteit, in het kader van het TKI- Agrofood programma 'TKI-AFLWV 1905' (PPS-nummer BO -59-001-004)

Wageningen Livestock Research

Wageningen, maart 2021

Deelnemende organisaties/bedrijven: Stichting Brancheorganisatie Kalversector (SBK), VanDrie Group, Denkavit, Pali Group \& LTO Nederland 
Puente-Rodríguez, D., I.D.E. van Dixhoorn, F.A. Hoorweg, L.R. Gollenbeek, C.G. van Reenen, A.J.A. Aarnink, N. Verdoes, en S. Bokma, 20211. Kalverstal van de toekomst - (bijna) Praktijkrijpe ontwerpconcepten. Wageningen Livestock Research, Rapport 1298.

Samenvatting NL: De vleeskalverhouderij wil de emissies van ammoniak, geur en broeikasgassen bij de bron reduceren. Hierdoor worden de emissies naar de omgeving beperkt en daardoor verbetert ook het stalklimaat, wat diergezondheid en welzijn ten goede komt. In dit rapport werken we een vijftal ontwerpconcepten uit die (bijna) praktijkrijp zijn ter inspiratie en voor ondersteuning voor ondernemers/sters die nu aan de slag willen/moeten in bestaande vleeskalverstallen.

Summery UK: The veal calf sector aims to reduce ammonia, odor and greenhouse gas emissions from barns. This has positive effects for the environment and improves the climate in the barn, which might benefit animal health and welfare. In this report we elaborate five design-concepts that are (almost) ready for implementation. The design-concepts are aimed at inspiring and supporting farmers who, right now, want/must take action to reduce emissions in existing veal calf barns.

Dit rapport is gratis te downloaden op https://doi.org/10.18174/542832 of op www.wur.nl/livestock-research (onder Wageningen Livestock Research publicaties).

\section{(cc) BY-NC}

Dit werk valt onder een Creative Commons Naamsvermelding-Niet Commercieel 4.0 Internationaallicentie.

(C) Wageningen Livestock Research, onderdeel van Stichting Wageningen Research, 2021

De gebruiker mag het werk kopiëren, verspreiden en doorgeven en afgeleide werken maken. Materiaal van derden waarvan in het werk gebruik is gemaakt en waarop intellectuele eigendomsrechten berusten, mogen niet zonder voorafgaande toestemming van derden gebruikt worden. De gebruiker dient bij het werk de door de maker of de licentiegever aangegeven naam te vermelden, maar niet zodanig dat de indruk gewekt wordt dat zij daarmee instemmen met het werk van de gebruiker of het gebruik van het werk. De gebruiker mag het werk niet voor commerciële doeleinden gebruiken.

Wageningen Livestock Research aanvaardt geen aansprakelijkheid voor eventuele schade voortvloeiend uit het gebruik van de resultaten van dit onderzoek of de toepassing van de adviezen.

Wageningen Livestock Research is NEN-EN-ISO 9001:2015 gecertificeerd.

Op al onze onderzoeksopdrachten zijn de Algemene Voorwaarden van de Animal Sciences Group van toepassing. Deze zijn gedeponeerd bij de Arrondissementsrechtbank Zwolle. 


\section{Inhoud}

Inleiding en kader

Het dilemma van bestaande vloeren-hokken

Scheiding van feces en urine onder de roostervloer d.m.v. een mestband

1.1 Emissie reducerende principes en potentie

1.2 Mogelijk nageschakelde processen en verwaarding 9

1.2.1 I.c.m. gecontroleerde compostering 9

1.2.2. I.c.m. vergisting? 9

$\begin{array}{lll}1.3 & \text { Toetsingskader } & 10\end{array}$

2

Opvang mest en urine in ammoniakarme vloeistof

2.1 Bijzonderheden 11

2.2 Vooruitblik $\quad 12$

$\begin{array}{lll}2.3 & \text { Toetsingskader } & 13\end{array}$

3 Mestschuif onder de roostervloer met lage urease-activiteit vanwege $\begin{array}{ll}\text { urease-remmer of rubber-uitvoering } & 14\end{array}$

$\begin{array}{lll}3.1 & \text { Betonvloer i.c.m. urease-remmer } & 14\end{array}$

3.2 Rubber uitvoering $\quad 15$

$\begin{array}{lll}3.3 & \text { Toetsingskader } & 16\end{array}$

$\begin{array}{llr}4 & \text { Mest koelen } & 17\end{array}$

$\begin{array}{lll}4.1 & \text { Toetsingskader } & 20\end{array}$

$5 \quad$ Toevoegingsmiddelen - mest aanzuren $\quad 21$

$\begin{array}{lll}5.1 & \text { Mest aanzuren } & 21\end{array}$

Literatuur 



\section{Inleiding en kader}

Het project 'Kalverstal van de Toekomst' streeft naar het integraal ontwerpen van duurzamere kalverstalsystemen. De doelstelling is om meerdere principes en concepten te integreren in bestaande en nieuwe kalverstallen om emissies (van ammoniak, ${ }^{1}$ methaan, andere broeikasgassen (BKG) en geur) te reduceren op zo'n wijze dat tegelijkertijd ook stalklimaat, diergezondheid (antibiotica gebruik) en dierenwelzijn verbeteren. Dit kan vervolgens leiden tot een verbetering van maatschappelijke acceptatie, arbeidsomstandigheden, werkplezier en rendement. Het project is een samenwerkingsverband van vertegenwoordigingsorganisaties en bedrijven in de agro-sector, namelijk Stichting Brancheorganisatie Kalversector (SBK), VanDrie Group, Denkavit, Pali Group, LTO Nederland samen met het onderzoeksinstituut Wageningen Livestock Research. Het project is medegefinancierd door de TopSector Agro \& Food en loopt door tot 2023. Het project is erop gericht om innovatieve emissie-reducerende maatregelen te identificeren en nieuwe concepten/systemen te ontwerpen. Dit om (binnen en 'buiten') klimaatvriendelijke stallen te ontwerpen en tegelijkertijd te voldoen aan andere duurzaamheidseisen die gelden vanaf 2023. Deze geïntegreerde ontwerpen voor emissiearme stallen moeten tevens een hoog niveau van dierenwelzijn en diergezondheid waarborgen. Daarmee draagt dit project bij aan zowel de verdere verduurzaming als aan de maatschappelijke acceptatie van de vleeskalverhouderij in Nederland.

In dit document werken we een aantal stalconcepten uit. Deze zijn afkomstig uit de literatuur, andere sectoren, een ontwerpatelier (juni 2020) en uit gesprekken met experts en worden gezien als kansrijk en op korte termijn toepasbaar om emissies van ammoniak, methaan en geur uit mest te reduceren. Deze ontwerpen zijn bedoeld voor wat we binnen het project het 'snelle spoor' noemen. Dat wil zeggen concreet en al op onderdelen in proefopstellingen of praktijkopzetten beproefd en nu nagenoeg gereed om op stalniveau toe te passen, te optimaliseren en emissie-technisch te valideren. De ontwerpen dienen als

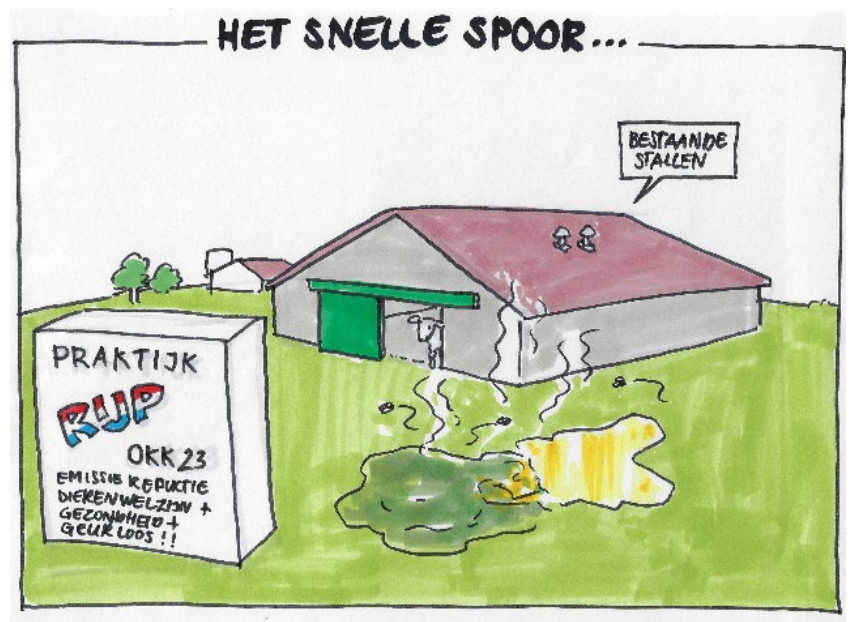
inspiratie voor kalverhouders en andere ketenpartijen en bieden tegelijkertijd een menukaart aan principes, maatregelen en technieken die (bijna) praktijkrijp zijn. Aangezien een brongerichte aanpak de insteek is geweest bij de ontwerpen zijn mechanisch geventileerde stallen voorzien van een luchtwasser hier niet als een optie verwerkt.

Hoewel onze focus op de stallen en het binnenklimaat ligt, worden onze systeemgrenzen hier bepaald door het primaire bedrijf als geheel. In andere veehouderij sectoren zien we regelmatig dat mest op het bedrijf verder wordt gescheiden/vergist/gecomposteerd/etc. in, maar ook (net) buiten de stal op het erf. Daarom is de stal de kern van de hier gepresenteerde ontwerpen waarbij onze werkelijke grens het primaire bedrijf is. Daarbij zijn we ons er van bewust dat afwentelingen elders plaats kunnen vinden, dus dat de emissies die niet in of rondom de stal plaatsvinden toch nog ergens anders kunnen ontstaan en toegerekend worden aan de vleeskalverhouderij. We kijken dus uitsluitend naar het (stal)systeem. We combineren en integreren technieken en principes in conceptontwerpen die werken binnen het gebied van excretie tot de afzet van mest. Waar mogelijk verwijzen we naar de literatuur waarin deze principes zijn uitgelegd. Op verschillende locaties in het land wordt al vanuit

\footnotetext{
${ }^{1}$ Vleeskalverstallen die vanaf 1 januari 2020 in gebruik worden genomen moeten voldoen aan de maximale emissienorm van $2,5 \mathrm{~kg}$ ammoniak per dierplaats per jaar (Besluit emissiearme huisvesting) wat een verlaging van $1 \mathrm{~kg}$ is ten opzichte van de huidige norm die van toepassing is op een traditioneel huisvestingssysteem. Echter, voor de vleeskalverhouderij zijn er (nog) niet veel goedgekeurde emissiearme stalsystemen en emissiefactoren op de RAV-lijst.
} 
privé-initiatieven met een aantal van deze concepten of principes geëxperimenteerd. Deze initiatieven zijn aangejaagd door wet- en regelgeving (denk bijvoorbeeld aan het ammoniak- en stikstofbeleid) en ondersteund door subsidiemogelijkheden. In dit document refereren we ook, waar mogelijk, naar de actuele status van deze initiatieven. De 5 conceptontwerpen zijn hier in grote lijnen uitgewerkt. Verschillende onderdelen kunnen met elkaar gecombineerd worden en aangepast naar de specifieke mogelijkheden/behoeften binnen het primaire bedrijf. Daarbij worden 4 van deze concepten getoetst aan verschillende criteria. ${ }^{2}$ Het toetsingskader is ontwikkeld en ingevuld d.m.v. expert consultatie, in interactie met de vertegenwoordigers van de kalversector en via een workshop (september 2020) met kalverhouders. De conceptontwerpen dienen als onderbouwing van mogelijke stalaanpassingen en als inspiratie voor ondernemers die nu aan de slag willen/moeten in bestaande vleeskalverstallen.

De 5 conceptontwerpen zijn:

$\begin{array}{ll}1 & \text { Scheiding van feces en urine onder de roostervloer d.m.v. een mestband } \\ 2 & \text { Opvang mest en urine onder de roosters in ammoniakvrije vloeistof } \\ 3 & \text { Mestschuif onder het rooster met lage urease-activiteit (vanwege urease remmer of } \\ & \text { rubber uitvoering) } \\ 4 & \text { Mest koelen } \\ 5 & \text { Toevoegingsmiddelen - mest aanzuren }\end{array}$

\section{Het dilemma van bestaande vloeren-hokken}

Het snelle-spoor, en de hieruit voortgekomen ontwerpconcepten, gaat uit van bestaande stallen en kansrijke, bijna bewezen technieken. Kalveren worden in groepen gehuisvest. Innovaties (zoals dichte emissiearme vloeren of mestrobots) op/rondom het loopoppervlak zijn nodig, maar 'nu' moeilijk uit te werken en in de praktijk te implementeren. Binnen het project 'Kalverstal van de toekomst' zullen we dit onderdeel, het 'verdiepende spoor,' nader onderzoeken en uitwerken.

Ten aanzien van methaan is de vloer, in principe, geen bron van emissie. In de literatuur kunnen we lezen dat bij blankvleeskalveren rond 30 à $40 \%$ van de ammoniakemissie uit de vloer ontstaat en $60-$ $70 \%$ vanuit de mestkelder. Bij rosévleeskalveren ligt deze verdeling rond de $50-50 \%$ (Groenestein et al., 2014; Heeres et al., 2017). Deze verdeling kan bij verschillende bedrijven anders liggen door veranderingen in bijvoorbeeld voersamenstelling. Hoe dan ook, voor ammoniak is de vloer een belangrijke bron van emissies.

Nota bene: Het is verstandig om de verdeling van de ammoniakemissie tussen mestkelder en het loop-/ligoppervlak in het achterhoofd te houden bij het lezen van en verder doordenken op de volgende systemen.

\footnotetext{
${ }^{2}$ Stalemissies reductiepotentie, investeringskosten, operationele kosten, economische voordelen/nadelen mest(verwaarding), dierenwelzijn en gezondheid, inpasbaarheid in bestaande stallen (bouwblok, vergunning, landschappelijke inpassing). Aspecten zoals voedselveiligheid vielen buiten het bestek van dit onderzoek.
} 


\section{Scheiding van feces en urine onder de roostervloer d.m.v. een mestband}

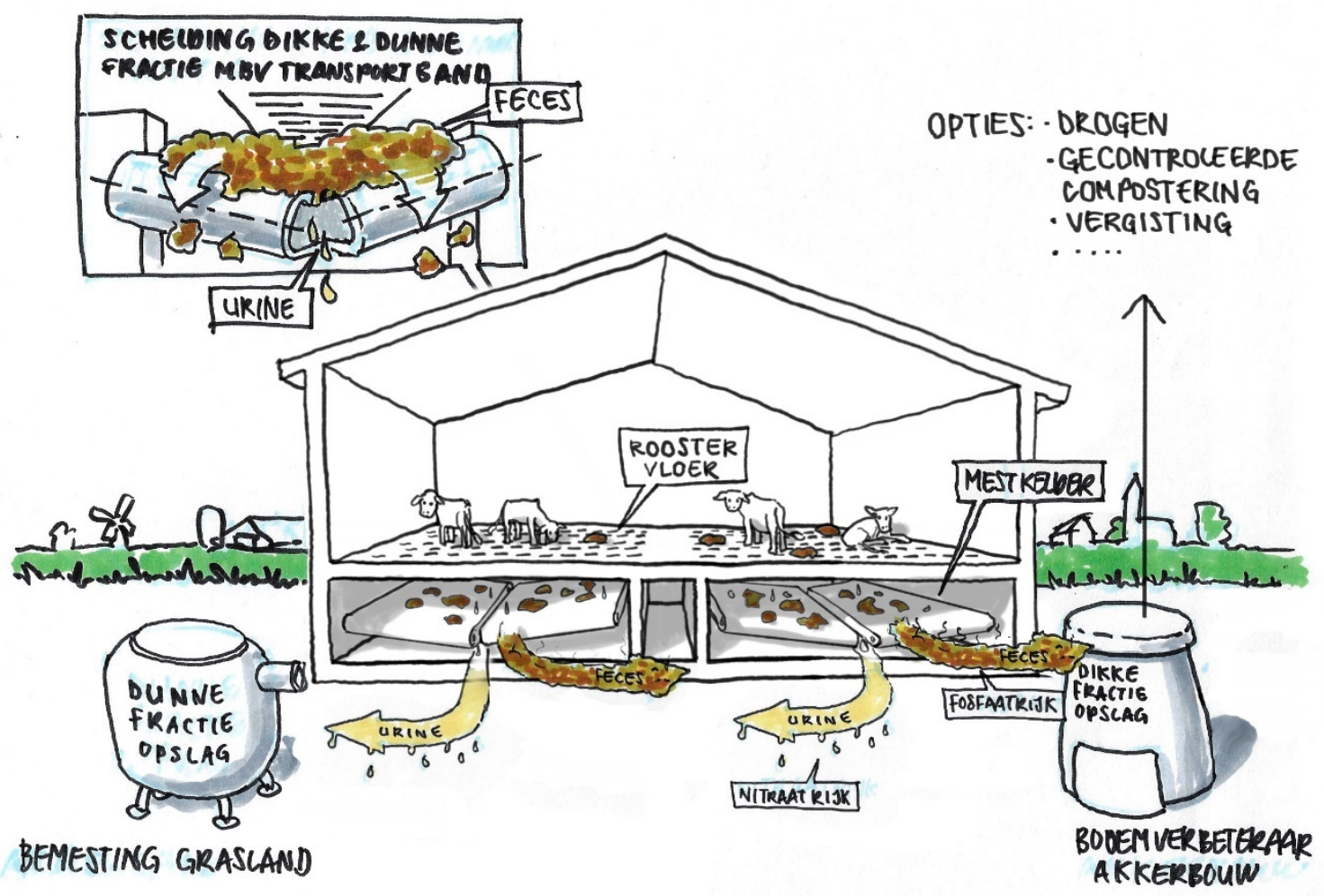

Vloeren zijn samen met het binnenklimaat de directe omgeving van het dier. Alle ontwerpconcepten zouden daarom bij een zacht en comfortabel loop- en lig-oppervlak en met een goed klimaat voor de kalveren kunnen starten. Dit oppervlak moet ook voldoende grip voor kalf en verzorger/ster bieden. Ten aanzien van reinheid en emissies is het belangrijk dat de mest en urine zo snel mogelijk naar beneden worden getransporteerd/doorgelaten.

Onder de roostervloer (bijvoorbeeld $30 \mathrm{~cm}$ ) is een V-vormige dichte (niet-geperforeerde) mestband gemonteerd onder een gering afschot (andere opties kunnen zijn: gering afschot naar één zijde; een geperforeerde doorlatende mestband te plaatsen). De urine stroomt naar het laagste punt van de band en wordt continu afgevoerd naar een afgesloten opslag (bij deze stal is er dan geen mestkelder zoals we die kennen). De vaste mest blijft op de band liggen totdat deze middels het afdraaien van de band wordt verwijderd. Dit gebeurt tussen de 1 keer per 2 uur en 1 - 2 keer per dag. De techniek hiervoor is afkomstig uit de legpluimveehouderij, waar het gebruik van dichte mestbanden een gangbare techniek is. Ook in de varkenshouderij (Aarnink et al., 2007) en de vleeskalverhouderij (Mosquera et al., 2019) is het systeem beproefd en zijn gunstige ammoniakreducties gemeten. 


\subsection{Emissie reducerende principes en potentie}

De emissie reducerende principes hierbij zijn: gescheiden opvang van feces en urine. Hierdoor komen (het ureum in de) urine en (het enzym urease in de) feces moeilijker dan bij de gangbare praktijk in contact met elkaar waardoor de vorming van ammoniak vertraagd wordt.
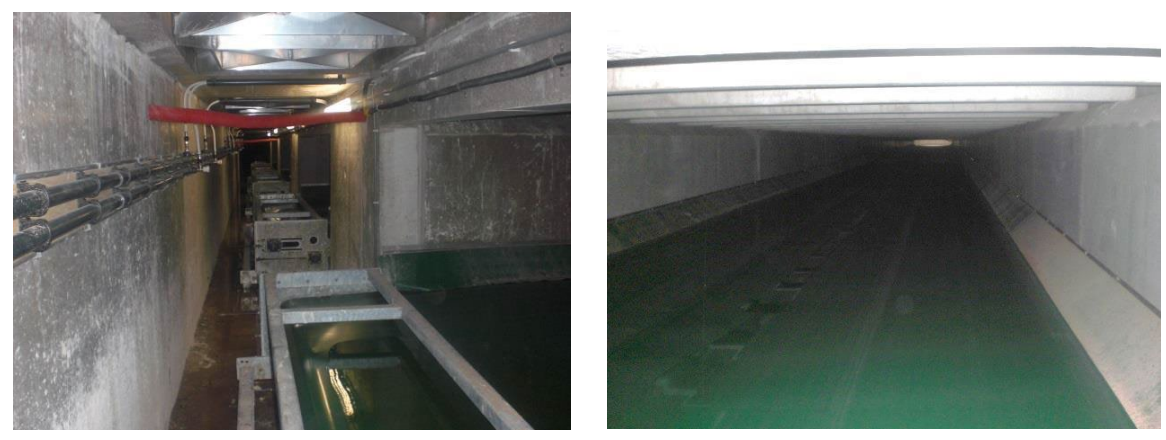

Foto 1

V-vormige mestband. Links: opvang ruimte van urine en feces. Rechts: mestband onder roostervloer (Mosquera et al., 2019).

Mosquera et al. (2019) rapporteren dat in een vleeskalverbedrijf de urease-activiteit op de daar gebruikte mestband laag is (vanwege de gebruikte materiaal en door vermindering van contacttijd tussen urine en feces) en dat gemiddeld slechts $25 \%$ van het ureum bij de mestband wordt omgezet in ammonium voordat de urine bij de opslag komt waardoor slechts een klein deel van in de vorm van ammoniak vanuit de mestput/mestband wordt uitgestoten.

Mosquera en zijn collega's rapporteerden op basis van een case-control onderzoek waarin een afdeling met het nieuwe systeem (d.w.z. mestband i.c.m. Grone Vlag vloer) wordt vergeleken met een andere afdeling met een gangbaar systeem (Mosquera et al., 2019), dat de ammoniakemissies 53\% lager was ten opzichte van de traditionele houten roostervloer met een mestopslag daaronder. De grootste winst qua emissiereductie werd onder de roostervloer (d.w.z. mestkelderemissie) geboekt.

De geuremissie was eveneens significant lager (47\%) t.o.v. de controle (Mosquera et al. 2019).

In het kader van een vleeskalverproject bij Mts Thelosen in Someren ${ }^{3}$ wordt ook met mestbanden geëxperimenteerd. Daar is een geperforeerde, urine-doorlatende mestband geïnstalleerd. In Someren zijn de eerste resultaten met een geperforeerde mestband tot nu toe wat wisselend geweest. De emissiereductie was bij aanvang hoog te noemen (>50\%) maar door vervuiling en verstoppingen is die tot nul of zelfs negatief geweest (persoonlijke communicatie, juni 2020; Monteny \& van Hoof 2020). Inmiddels is een verbeterde uitvoering aangebracht waaraan vervolgproefmetingen plaatsvinden. Dit wijst op de behoefte aan een optimalisatie- en implementatietraject om een praktisch, robuust en goed werkend systeem te kunnen ontwikkelen specifiek voor de kalverhouderij.

Moeilijker is het om informatie over de methaanemissie te vinden. De aandacht voor de reductie van de methaanemissie is relatief nieuw, principes en maatregelen zijn daarom tot nu toe met name in experimentele contexten uitgeprobeerd en de praktijkrijpheid en ervaring over de effectiviteit loopt achter bij die van ammoniak. Daarbij wordt in de literatuur meestal gerapporteerd over de reductie potentie van één enkele maatregel en hier hebben we het over combinaties van maatregelen. Als de mest frequent en volledig uit de kelder wordt verwijderd heeft dat bijvoorbeeld positieve effecten op de reductie van methaanemissie uit de mest in de stal. In de literatuur wordt gerapporteerd dat het frequent verwijderen van drijfmest uit de mestkelder (bijvoorbeeld d.m.v. een pomp, maar ook zoals hier door een mestband) en die drijfmest vervolgens in een gasdichte opslag houden i.c.m. een aanvullende techniek om gasvorming tegen te gaan (zoals koeling, zie hieronder), te oxideren (in ontwikkeling, maar nog niet praktijkrijp voor veehouderijdoeleinden), danwel te benutten (vergisting)

\footnotetext{
${ }^{3}$ Op het bedrijf Mts. Thelosen in Someren worden sinds oktober 2018 een aantal systemen getest voor blankvleeskalveren. Het project is mede gefinancierd door de Provincie Noord-Brabant (Monteny \& van Hoof 2020).
} 
10 tot $80 \%$ methaanemissie kan reduceren (Groenestein et al., 2010; Massé et al., 2016; Šebek et al., 2016; Willeghems et al., 2016).

In dit ontwerpconcept worden urine en mest dus apart gehouden en opgeslagen. Dit kan ook positieve effecten hebben voor het verwaarden van meststromen.

\subsection{Mogelijk nageschakelde processen en verwaarding}

De urinefractie kan als $\mathrm{N}$-meststof (tot de gebruiksnorm van $170 \mathrm{~kg}$ of $230 \mathrm{~kg}$ per ha) worden gebruikt of met een verdere bewerkingsstap als kunstmestvervanger worden ingezet. ${ }^{4}$ Eventueel kan de urine licht worden aangezuurd om NH3-vervluchtiging tegen te gaan.

Feces kunnen in een afgesloten opslag buiten de stal opgeslagen worden, of eventueel verder worden gescheiden i.c.m. een proces van droging en/of compostering.

\subsubsection{I.c.m. gecontroleerde compostering}

Door (aerobe) compostering (in een composteringstrommel) kunnen de emissies van $\mathrm{CH}_{4}$ worden beperkt. In dit proces zullen wel emissies van $\mathrm{NH}_{3}$ en $\mathrm{N}_{2} \mathrm{O}$ plaats vinden (Hoeksma et al., 2012). Een optie is om dit proces in een composteringstrommel uit te voeren in combinatie met een luchtwasser om ammoniak op te vangen. Na bijvoorbeeld ongeveer 12-13 uur verblijfstijd en bij de kern een temperatuur van rond $60^{\circ} \mathrm{C}$ is dit materiaal een gehygiëniseerd product dat bijv. geëxporteerd kan worden. Eventueel kan het materiaal verder composteren/drogen en korrelen (met een droge stofgehalte van > 90\% (Hoeksma et al., 2012) en gecommercialiseerd worden. Bij een (nog te bepalen) langere verblijfstijd van de dikke fractie in de trommel (die in de praktijk nog vaak te kort is) en de temperatuur die momenteel bereikt wordt, ontstaat een stabiel materiaal dat weinig tot niks kan emitteren.

\subsubsection{I.c.m. vergisting?}

Om emissies uit (mest of) de dikke fractie te voorkomen kan deze ook vergist worden. Bij vergisting helpen micro-organismen onder anaerobe omstandigheden om de organische stof in biogas $\left(\mathrm{CO}_{2}\right.$ en $\mathrm{CH}_{4}$ ) om te zetten. Dit is dus een bron van energie. Efficiënte biogas-vergisters kunnen $\mathrm{CH}_{4}$ emissies verminderen met 60 tot $80 \%$, die anders uit de mest tijdens de opslag in de stal of daarbuiten geproduceerd zouden worden (GRA, 2013). Voorwaarde is dan wel dat mest zo snel mogelijk na te zijn uitgescheiden vergist wordt. Kroes et al (Kroes et al., 2016) melden dat bij het ECOFERM rosé bedrijf er twee mest-stromen zijn. De ene ondergaat een scheidingsproces d.m.v. mestschuif in combinatie met een hellende vloer (zie ontwerpconcept 3, hieronder) en de andere van drijfmest. In 2016 gaven deze twee stromen samen 16.761 ton/jaar mest met een ds-gehalte van 12,8\% (Kroes et al., 2016). "De drijfmest uit de oude stal plus de feces uit de nieuwe stal gaan gezamenlijk naar de monovergister. De samenstelling van het digestaat komt in de praktijk uit op 6-7 g/kg N en 2,5-3 $\mathrm{g} / \mathrm{kg}$ P2O5. De opbrengsten aan biogas lagen tussen 30 en $40 \mathrm{~m}^{3}$ per ton" mest (ibid.). "Het bedrijf is gestopt met vergisting omdat de financiële opbrengsten te laag waren om de investeringen in het oplossen van technische problemen terug te verdienen" (Kees Kroes, persoonlijke communicatie, juni 2020). Vergisters zijn efficiënt en vereisen aandacht en een specifieke bedrijfsvoering, subsidie en verdienmodel.

Een relevante vraag is of mest van blankvleeskalveren geschikt is voor vergisting. Vroeger kregen blankvleeskalveren alleen melk verstrekt. De mest was daardoor erg dun met weinig droge stof. Het laatste decennium is het rantsoen en de mest van de kalveren sterk veranderd. Er wordt gerapporteerd dat de gemiddelde samenstelling van dunne mest nu meer dan $4 \mathrm{~kg}$ stikstof/ton bevat en $45 \mathrm{~kg}$ droge stof /ton (KWIN, 2020). Het huidige rantsoen bevat veel kracht- en ruwvoer c.q. vastvoer. Toch zal bij dit nog relatief lage percentage droge stof (en organische stof) monovergisten

\footnotetext{
${ }^{4}$ Als we urine bewerken met omgekeerde osmose komt er een concentraat en water uit. Dat concentraat met $\mathrm{N}$ en $\mathrm{K}$ mag boven de gebruiksnorm ( $170 / 230 \mathrm{~kg}$ ) worden aangewend als kunstmestvervanger.
} 
van mengmest van blankvleeskalveren niet rendabel zijn. Het vergisten van alleen de feces verdient het wel om nader onderzocht te worden.

\subsection{Toetsingskader}

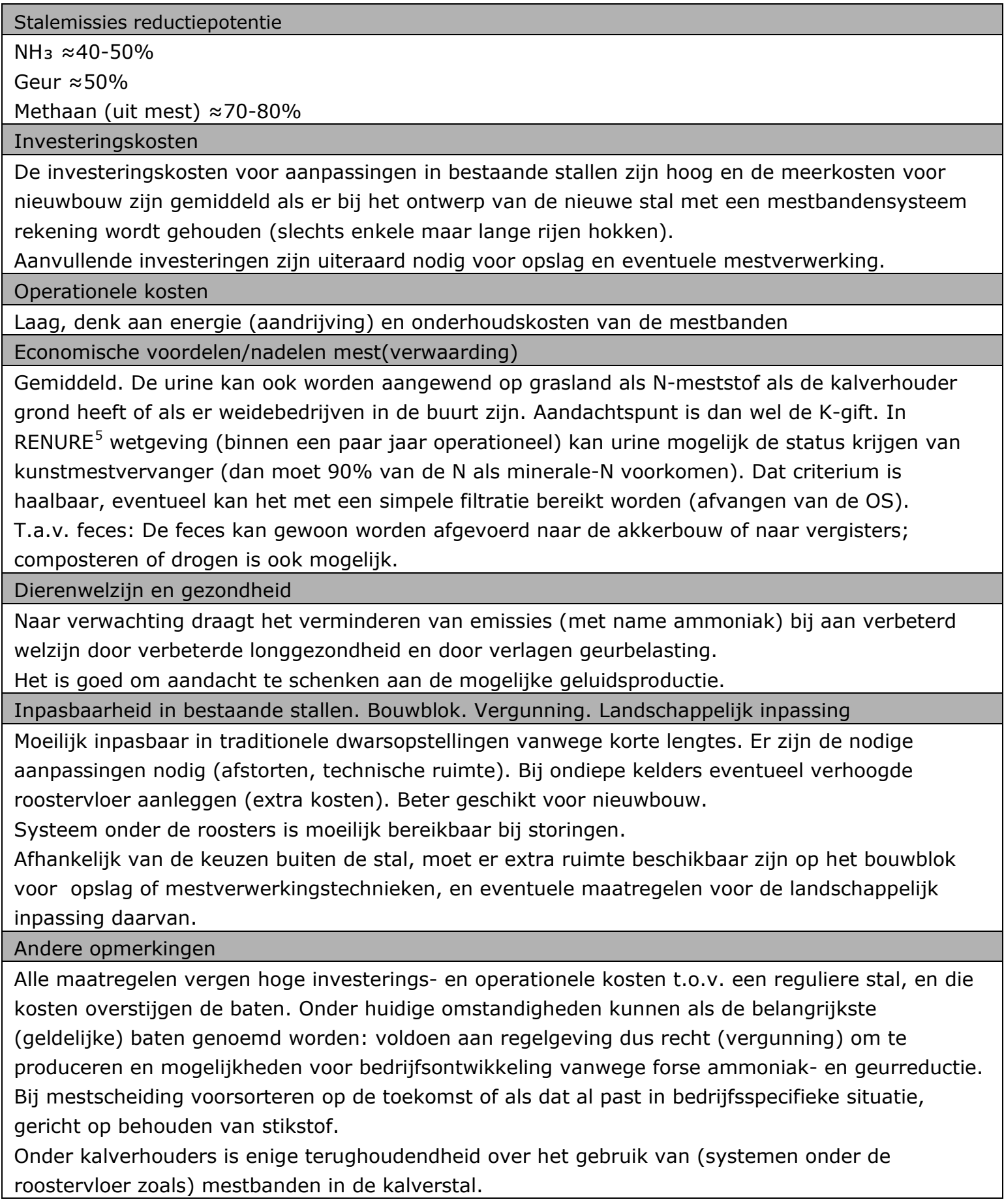

\footnotetext{
${ }^{5}$ REcovered Nitrogen from manURE (RENURE). Dit zijn de dierlijke meststoffen die binnenkort volgens de criteria van de EU Nitraatrichtlijn kunstmeststoffen kunnen vervangen. https://www.Ito.nl/mede-dankzij-inbreng-Ito-een-nieuwe-stapvooruit-in-kunstmestvervanging/ (geraadpleegd november 2020).
} 


\section{Opvang mest en urine in ammoniakarme vloeistof}

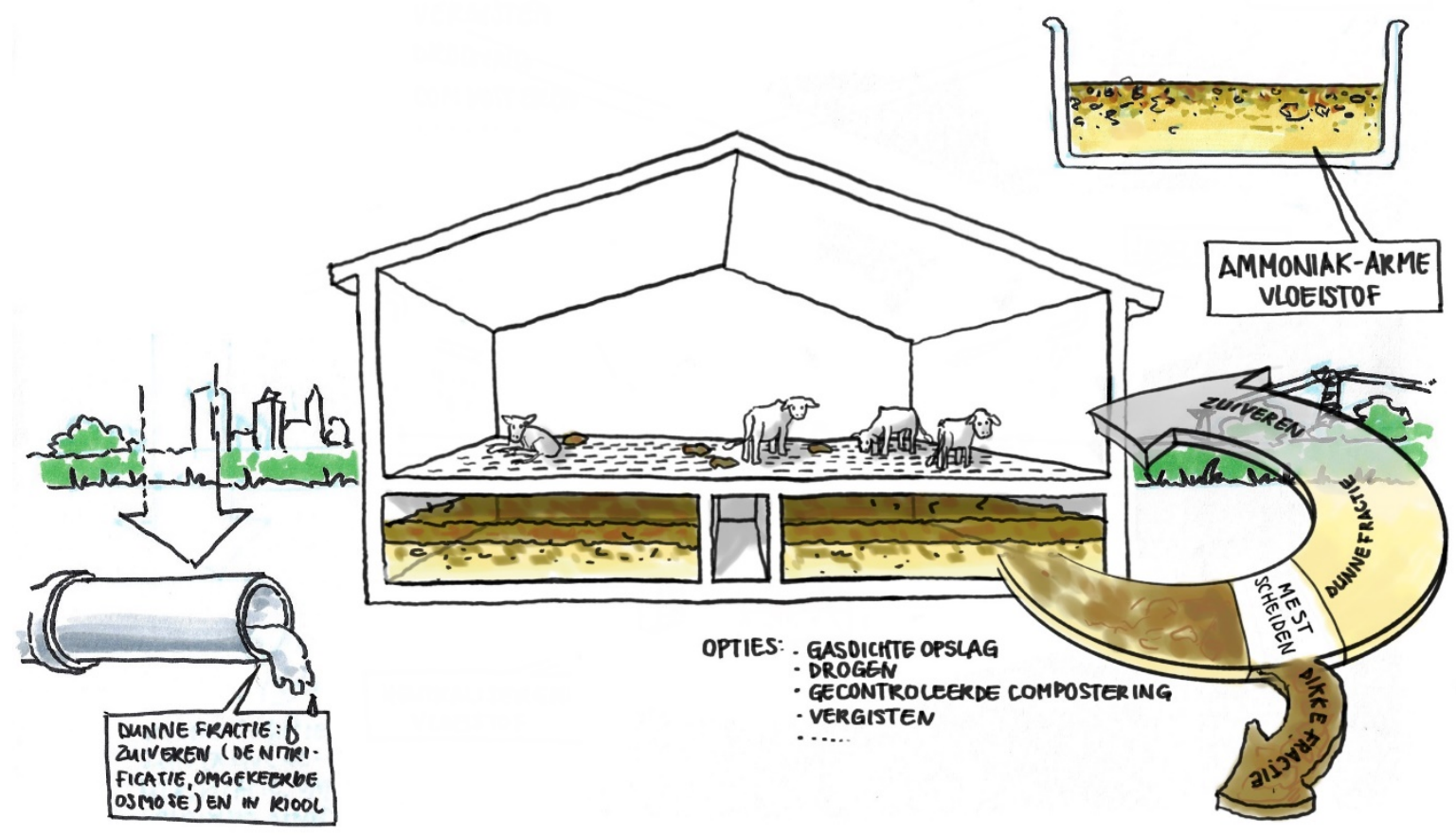

In dit conceptontwerp ligt (ook) een goede comfortabele vloer met grip. Bovendien is deze vloer goed doorlatend voor feces en urine.

De kern van het systeem is dat verse feces en urine worden opgevangen in een laag ammoniakarme vloeistof in het mestkanaal. Hierdoor vindt verdunning plaats en wordt de vervluchtiging van ammoniak uit de vloeistof sterk geremd. De vloeistof met daarin mest en urine wordt dagelijks afgevoerd uit het mestkanaal en vervangen door verse vloeistof. Als vloeistof kan water worden gebruikt of bijvoorbeeld de dunne fractie na mestscheiding die door middel van biologische afbraak in een zuiveringsinstallatie ammoniak-arm is gemaakt.

Het systeem is daarmee in beginsel toepasbaar in vrijwel alle vleeskalverstallen met relatief ondiepe kelders. In de varkenshouderij zijn in het verleden verschillende bereidingsprincipes van de vloeistof onderzocht (zie bijvoorbeeld Hoeksma et al., 1993). Hiermee zijn in varkensstallen reducties van ammoniak van ca 40 tot $60 \%$ bereikt, of te wel ongeveer $60-80 \%$ van de kelderemissie.

Ook de geur- en broeikasgasemissies vanuit de kelder zullen door de verdunning en frequente verwijdering afnemen.

\subsection{Bijzonderheden}

Feces en urine worden opgevangen in een ammoniak- en geurvrije vloeistof. Voor het verkrijgen van deze ammoniumarme vloeistof wordt een nitrificatie-denitrificatie proces gevolgd. Dit is een proces waarbij de te behandelen vloeistof eerst lang en intensief wordt belucht (het kan ook worden 
aangezuurd). De ammonium-N (en een groot deel van de organische stof) wordt daarbij afgebroken en omgezet in nitraat. Door vervolgens een energiebron toe te voegen en de omstandigheden anaeroob te maken treedt denitrificatie op, en vervliegt het stikstof in het nitraat naar de lucht in de vorm van stikstofgas $\left(\mathrm{N}_{2}\right)$. Bij dit proces kan ook lachgas vrijkomen, een sterk broeikasgas. De mate waarin dit gebeurt is sterk afhankelijk van de procesbeheersing. Procesbeheersing is bij de verdere ontwikkeling en toepassing van deze techniek dan ook een belangrijke voorwaarde. Een open vraag hierbij is of de nitrificatie-/denitrificatiestappen en het verliezen van stikstof een verstandige keuze is binnen de huidige trend naar kringlooplandbouw waarin gestreefd wordt naar een kleiner aandeel van kunstmest en alternatieven hiervoor worden gezocht.

Bij dit systeem wordt een mestscheidingsproces toegepast. Dat kan bijvoorbeeld gebeuren met een decanter-centrifuge om te zorgen dat de dunne fractie weinig organische stof bevat. De dunne fractie wordt naar de beluchtingstank geleid. De gezuiverde dunne fractie kan op het riool geloosd worden. Dezelfde gezuiverde vloeistof kan ook gebruikt worden als geur en ammoniumarme vloeistof. De dikke fractie vereist ook aandacht (denk aan afvoeren, vergisting, droging/hygiëniseren/composteren etc.).

\subsection{Vooruitblik}

Er zijn bedrijven ${ }^{6}$ die nitrificatie-/denitrificatiesystemen commercialiseren om mest te verwerken. Het systeem wordt momenteel o.a. op een kalverbedrijf in Groenlo (Ottink Mestverwerking) gebruikt. In Groenlo wordt rond de $35.000 \mathrm{~m}^{3}$ kalvermest van eigen bedrijf, en daarnaast varkensmest uit omringende bedrijven verwerkt. $75 \%$ van de mest wordt als gezuiverde dunne fractie geloosd op het riool (na verwerkingen) en de overige $25 \%$ dikke fractie gaat op dit moment naar een biogasinstallatie in de directe omgeving. ${ }^{7}$ De techniek van opvang in (beluchte) spoelvloeistof is ook getest in de stal in Someren. Betrokkenen melden dat er door storingen nog geen goed beeld is over de reductiepotentie voor wat betref ammoniakemissie, en dat het systeem nog wel kwetsbaar is in deze uitvoering (persoonlijk communicatie, juni 2020; Monteny \& van Hoof 2020). Betrokkenen beschouwen het systeem desondanks nog wel als 'perspectief vol'.

\footnotetext{
${ }^{6}$ https://www.kamplan.com/nl/mestverwerking/ (geraadpleegd juli 2020).

${ }^{7}$ https://www.kamplan.com/nl/projecten/mestverwerking/biologische-mestverwerkingsinstallatie/
} 


\subsection{Toetsingskader}

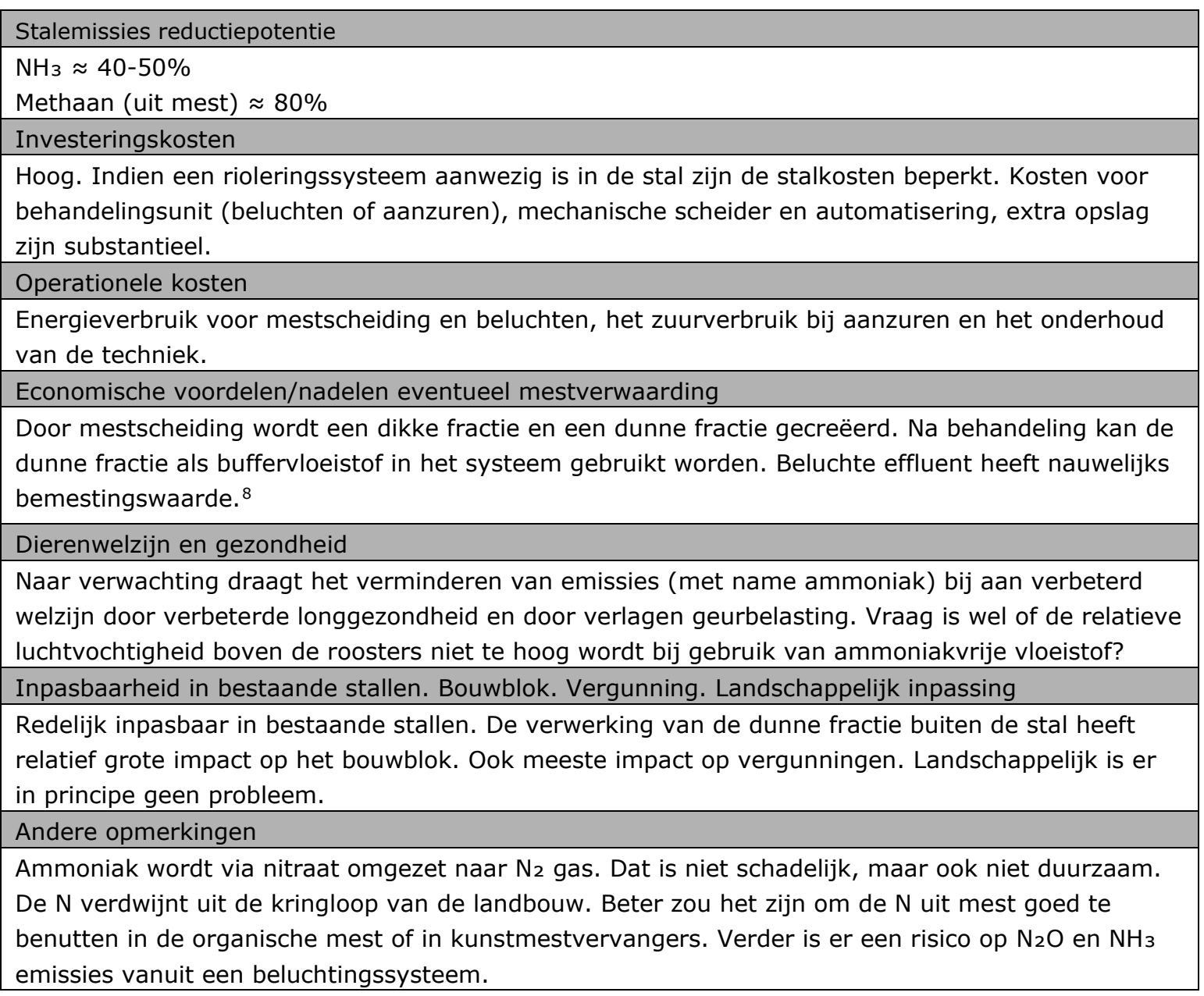

\footnotetext{
${ }^{8}$ Er zijn verschillende mogelijkheden om hier innovaties voor te ontwikkelen. Men zou bijvoorbeeld een spoelsysteem kunnen maken waar geen beluchting wordt toegepast, maar omgekeerde osmose. Dan kan het effluent gebruikt worden om te spoelen en de rest kan worden geloosd. Dan kan men ook een dikke fractie maken om af te zetten naar akkerbouw. De tweede innovatie is: de beluchting centraal laten geschieden op de kalvergierbewerkingsinstallatie en de spoelvloeistof via de persleiding naar de bedrijven brengen. Dan moeten uiteraard ook de pathogenen gedood worden.
} 


\section{$3 \quad$ Mestschuif onder de roostervloer met lage urease-activiteit vanwege urease-remmer of rubber-uitvoering}

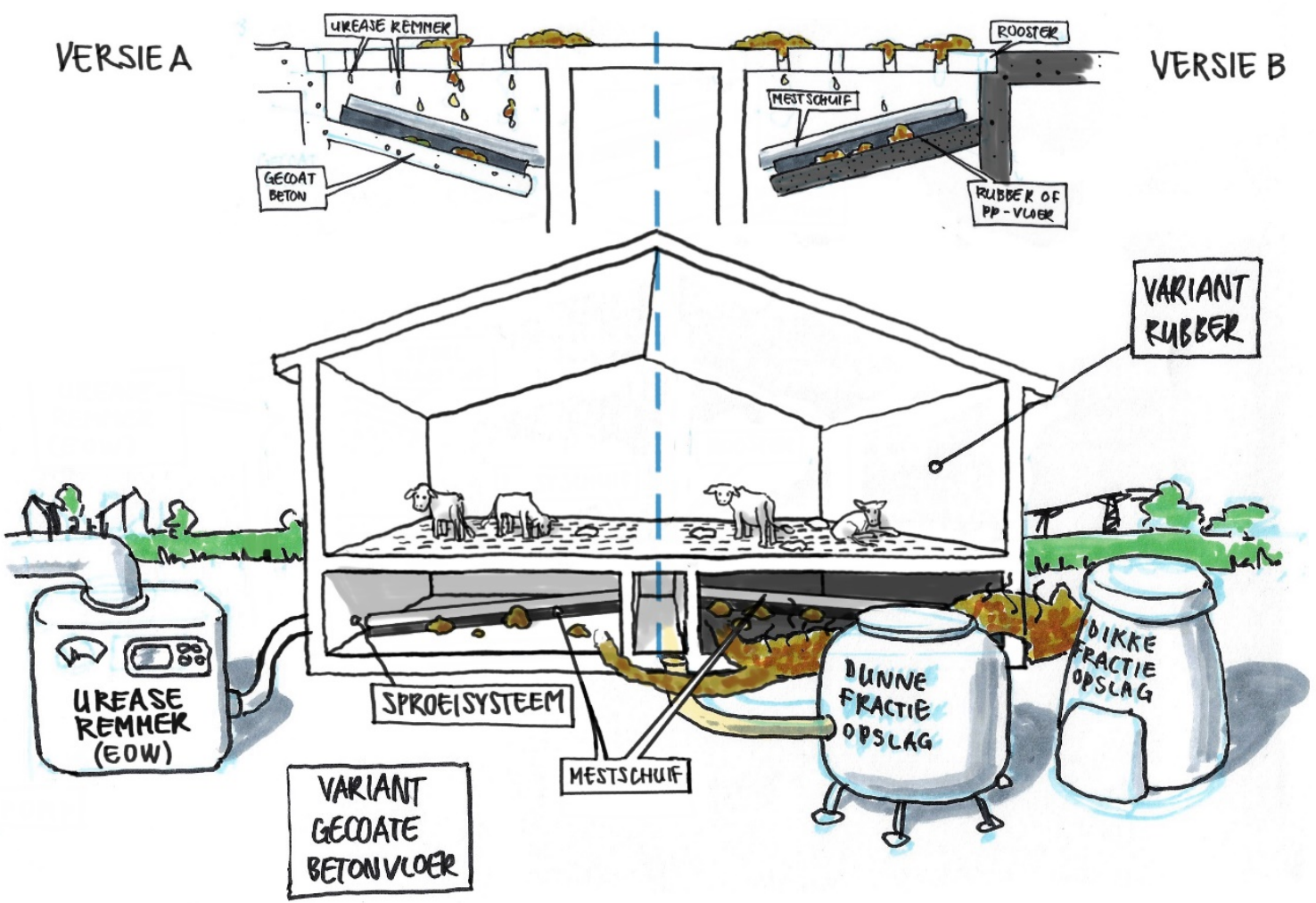

Onder de roostervloer is een ondiep mestkanaal aanwezig met een gladde en vlakke, maar licht hellende vloer van beton met coating of beton met rubber/polyethyleen/polypropyleen welke door een mestschuif wordt gereinigd.

\subsection{Betonvloer i.c.m. urease-remmer}

Onder de roostervloer vallen feces en urine op een gladde, gecoate hellende betonvloer. ${ }^{9}$ Door het afschot loopt de urine continu weg (> 1\%). Urine/gier wordt in een afgedekte/afgesloten opslag opgeslagen. Om te voorkomen dat bij deze opslag emissies vrijkomen kan er bijvoorbeeld een koelsysteem geïnstalleerd worden (zie hieronder). Urine/gier kan op grasland of bij de akkerbouw gebruikt/afgezet worden.

Een mestschuif verwijdert de feces (bijvoorbeeld elke 2 uur overdag en elke 4 uur's nachts; experimenten en praktijkervaringen zullen dit nader kunnen specificeren). Er is een sproeisysteem (op de mestschuif, of een vast sproeisysteem vanaf de zijkant) om water en/of een desinfecterend middel of een urease-remmer toe te passen. Ammoniak ontstaat als ureum in de urine in contact komt met het enzym urease. Urease wordt geproduceerd door bacteriën op de vloer of in de feces. Uit eerder

\footnotetext{
${ }_{9}^{9}$ Slijtage, bevuiling waar (urease enzym)bacteriën kunnen vasthechten zijn problemen die als eerder zijn gerapporteerd (zie bijvoorbeeld, van de Sande-Schellekens et al., 1995).
} 
onderzoek (Aarnink \& Puente-Rodríguez, 2017; Puente-Rodríguez \& Bos, 2019) is gebleken dat de urease-activiteit sterk kan worden gereduceerd door toepassing van een desinfectiemiddel op de vloer. Het meest perspectiefvolle middel is geëlektrolyseerd water ${ }^{10}$ (EOW: 'electrolyzed oxidized water'). Uit voornoemd onderzoek blijkt dat deze middelen bij éénmalige behandeling van de vloer de urease-activiteit op deze vloer gedurende minimaal 2 dagen sterk kan reduceren. Verder kan EOW tegen relatief lage kosten op het bedrijf zelf worden aangemaakt. Nadat het zijn werking heeft gehad wordt EOW weer snel afgebroken tot onschadelijke componenten waardoor dit middel ook wordt gebruikt voor bijvoorbeeld vermindering van microbiële besmetting op voedselverwerkende oppervlakken, roestvrij staal, glaswerk in het laboratorium of medische en tandheelkundige voorzieningen (Sakurai et al. 2002; Al-Haq et al. 2005; Mukhopadhyay et al. 2012; Buncic \& Sofos 2012). Uit onderzoek is gebleken dat een behandeling met EOW op een betonnen sleuvenvloer op een melkveebedrijf na reiniging van de vloer met een borstel en een schraper de ammoniakemissie vanaf de vloer met 68,2\% reduceert t.o.v. water dat als controle werd gebruikt (Puente-Rodríguez \& Bos 2019, blz. 126; Aarnink \& Puente-Rodríguez 2017). Bij intensief toepassen van EOW op de vloer kan de urease-activiteit naar de (bijna 0) achtergrondwaarde worden teruggebracht. Momenteel wordt dit systeem verder ontwikkeld binnen verschillende veehouderijsectoren.

De dikke fractie kan afgezet worden (naar een mestverwerkingsbedrijf bijvoorbeeld), aeroob (voor methaan) of gekoeld gehouden of worden vergist (zie discussie hierboven).

\subsection{Rubber uitvoering}

Hetzelfde systeem onder de roosters kan ook gebruikt worden zonder een urease-remmer (EOW). In dat geval is het kelderoppervlak niet van beton, maar wordt die voorzien van een toplaag van bijvoorbeeld thermoplastisch rubber. Maar ook andere kunststoffen zoals polyethyleen ${ }^{11}$ of rubberachtige coatings en materialen kunnen, theoretisch, toegepast worden. Een thermoplastisch elastomeer materiaal wordt bijvoorbeeld gebruikt in de toplaag van de Groene Vlag. ${ }^{12}$ Onderzoek heeft laten zien dat de urease-activiteit van dit materiaal $90 \%$ lager is dan van een traditionele betonroostervloer in de melkveehouderij (Kasper et al., 2010; zie ook Van den Hoorn et al., 2009; Puente-Rodríguez \& Bos, 2019). Uit onderzoek blijkt dat ook op andere typen rubber geen of nauwelijks een biofilm wordt gevormd en daardoor een lage urease-activiteit heeft. Experimenten hebben laten zien dat het type rubber dat gebruikt wordt bij de merknaam Eco-Vloer ${ }^{13}$ een vergelijkbare urease-activiteit liet zien als de Groene Vlag (Puente-Rodríguez \& Bos 2019, blz. 139140). Of dit het geval is met andere rubber-materialen zou onderzocht moeten worden.

In dit concept loopt de urine weg dankzij het afschot en de gladheid/dichtheid van het oppervlak. De feces worden door een mestschuif getransporteerd. Deze mestschuif is ook van polypropyleen/polyethyleen gemaakt om te zorgen dat er geen slijtage plaatsvindt en om emissies te voorkomen. Mocht de mestschuif bijvoorbeeld elke 2 uur zijn beurt doen en bij een goede werking (water zou eventueel gebruikt kunnen worden voor de volledigheid van het reinigen) zou er in de kelder, een theoretische reductie van rond $90 \%$ van de kelderemissie van ammoniak en van circa $100 \%$ aan methaan kunnen zijn.

Voor zo ver wij weten is er met dit systeem nog niet geëxperimenteerd. Een experimenteel- en ontwikkelingstraject is hiervoor vereist.

\footnotetext{
${ }^{10}$ EOW, electrolyzed oxidizing water; pH 6,8 - 7,0; oxidation reduction potential (ORP) > 930; FAC 500 ppm; Aquaox BV, Soest (Puente-Rodríguez \& Bos, 2019).

${ }^{11}$ Een aandachtspunt van veel harde kunststoffen vormen de uitzettingscoëfficiënten, d.w.z. de rek en krimp vermogen bij temperatuur wisselingen.

${ }^{12}$ Ontwikkeld door de Irish Custom Extruders Ltd en in Nederlad verkrijgbaar.

${ }^{13}$ https://andersbeton.com/nl/eco-vloer (geraadpleegd juli 2020).
} 
Nota bene: Deze twee systemen gaan uit van een scheiding van feces en urine. Dit past binnen de trend in de veehouderij om meststoffen beter te benutten om o.a. het beter afsluiten van kringlopen (kringlooplandbouw). Daarnaast is het effectief om de ammoniakemissie te beperken (zie bijvoorbeeld De Vries 2014). Het systeem is echter zeker ook denkbaar bij toepassing van drijfmest en die drijfmest frequent uit de mestkelder te verwijderen. Uit onderzoek is gebleken dat het 2 en 4 keer tijdens de zomerperiode leegmaken van de mestopslagtank de methaanuitstoot (uit melkkoeien- en varkensmest) gemiddeld met respectievelijk 40 en 80\% vermindert (Massé et al., 2016; zie ook Willeghems et al., 2016). Voor de reductie van de ammoniakemissie wordt echter een minder groot percentage verwacht.

\subsection{Toetsingskader}

Stalemissies reductiepotentie

$\mathrm{NH}_{3} \approx 40-50 \%$ (winst uit de kelder; geen effect op de emissie van de roostervloer)

Methaan (uit mest) $\approx 80-90 \%$ (alle mest wordt uit de stal verwijderd)

Investeringskosten

Hoog. Aanpassingen kelder nodig (afschot, afstort dikke fractie goot dunne fractie incl. pompen).

EOW installatie. Tevens rubber of coating. In nieuwe stallen kan er direct rekening worden

gehouden met de aangepaste kelderuitvoering.

In alle gevallen moet er ook in mestopslag buiten de stal worden geïnvesteerd.

Operationele kosten

Redelijk hoog (t.a.v. huidige situatie in bestaande stallen). Het energiegebruik van een mestschuif is relatief laag. Maar de combinatie van verschillende technieken en onderhoud zorgen voor hogere kosten.

Economische voordelen/nadelen eventueel mestverwaarding

Zie argumenten scheiding d.m.v. een mestband. Twee gescheiden mestfracties. Er treedt meer vermenging op van feces en gier dan bij de mestband. Gier en feces kunnen separaat aangewend of afgevoerd worden, in specifieke situaties leidt dit tot voordelen. Mogelijk in de toekomst voordeel. Behouden van stikstof in de mest is voordelig maar bij een overschot aan stikstof op het bedrijf kan het nadelig zijn

Dierenwelzijn en gezondheid

Naar verwachting draagt het verminderen van emissies (met name ammoniak) bij aan verbeterd welzijn door verbeterde longgezondheid en door verlagen geurbelasting.

Inpasbaarheid in bestaande stallen. Bouwblok. Vergunning. Landschappelijk inpassing

Moeilijk inpasbaar in bestaande stallen. Er zijn de nodige ingrijpende aanpassingen nodig (schuine putvloer, mestschuiven, afstorten, technische ruimte).

Opslag buiten stal dus inpasbaarheid in bouwblok kan problemen opleveren. Vergunningen: Is van de Rav-lijst gehaald vanwege het uitblijven van emissiemetingen. Momenteel wordt dit systeem verder ontwikkeld. Landschappelijk geen probleem.

Andere opmerkingen

Alle maatregelen zijn ten opzichte van een reguliere stal in termen van investerings- en operationele kosten hoog, en de kosten overstijgen de baten. Onder huidige omstandigheden kunnen als de belangrijkste (geldelijke) baten genoemd worden: voldoen aan vergunning dus recht om te produceren, verbeterde gezondheid mens en dier wat mogelijk leidt tot hogere productie, met mestscheiding voorsorteren op de toekomst of indien dat al past in de bedrijfsspecifieke situatie, behouden van stikstof. 


\section{$4 \quad$ Mest koelen}

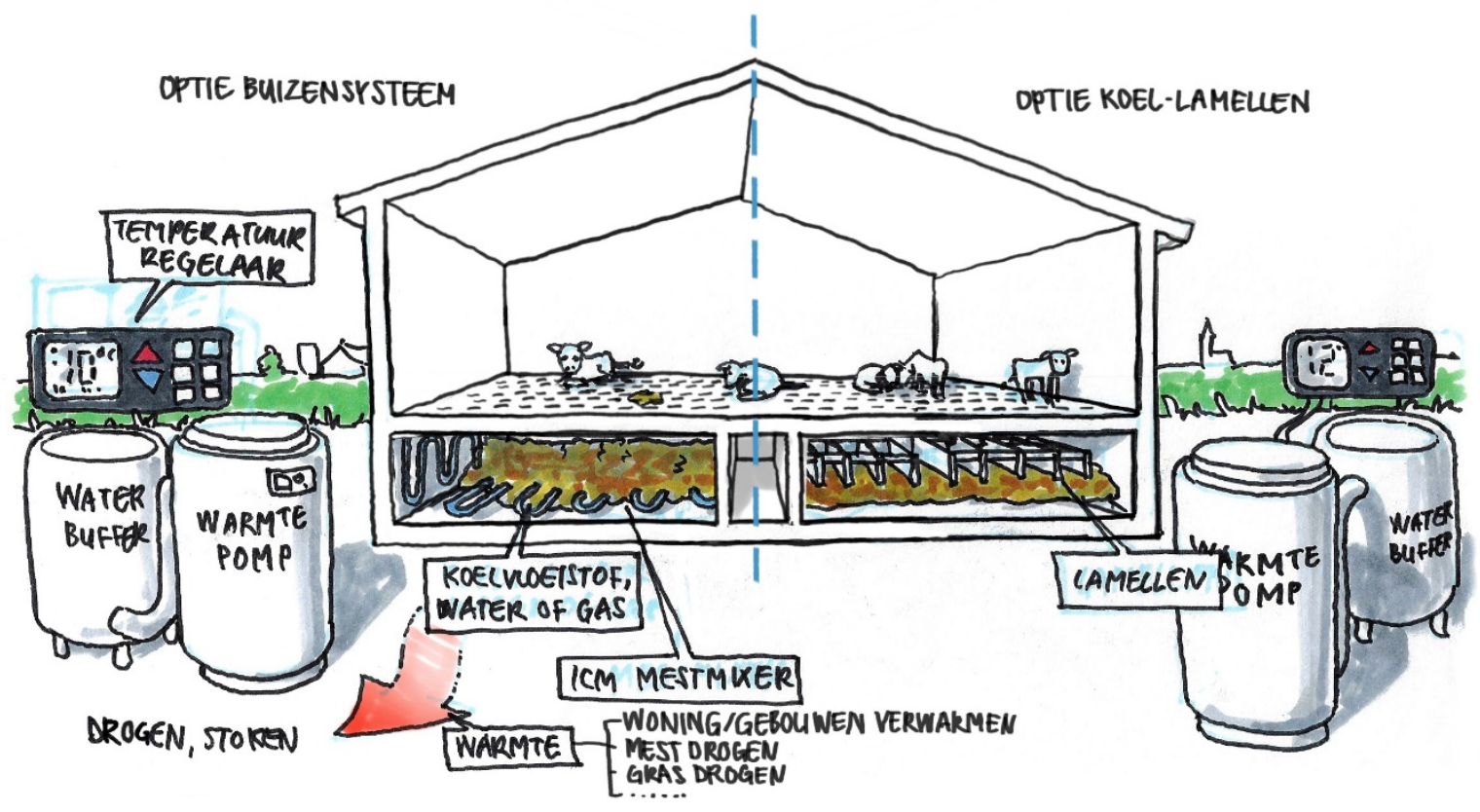

Het koelen van mest kan plaatsvinden in de huidige mestkelders. Door het koelen van mest kan je zorgen dat ammonium minder makkelijk als ammoniak emitteert. Met temperatuur kunnen daarnaast ook $\mathrm{CH}_{4}$-gerelateerde processen in de mest gestuurd worden. Als de temperatuur laag is, dan is de bacteriële activiteit ook laag waardoor alle omzettingsprocessen (digestie) langzamer verlopen en dus ook minder methaanvorming en emissies plaatsvinden (Groenestein et al., 2012; Borhan et al., 2012; GRA, 2013).

Een simpele manier om mest koeler te bewaren is de opslagduur van de mest in de stal verkorten, omdat de stal vaak warmer is dan buiten. Dit geldt vooral voor varkensstallen die verwarmd worden. Groenestein en haar collega's (2012) berekenden op basis van de Arrhenius-vergelijking dat met een gemiddelde buitenlucht temperatuur in Nederland van $10^{\circ} \mathrm{C}$ de methaanemissies in de varkensstallen tussen 23 en $43 \%$ gereduceerd kunnen worden. Bij rundvee is het verschil tussen de temperatuur binnen en buiten kleiner en zal een dergelijke maatregel dus minder effect hebben.

Door de temperatuur te verlagen wordt het proces van ammoniakvorming vertraagd. Van Dooren en Mosquera (2019) melden dat het koelen van varkensmest in de Rav is opgenomen met een ammoniakemissiereductie van 44-52\% bij vleesvarkens. Deze onderzoekers (zie ook de gebruikte referenties in dat rapport) concluderen dat in de melkveehouderij "een emissiereductie van 10-15\%" haalbaar lijkt. Voor vleeskalveren schatten Smits et al in 2005 in dat door mest te koelen er een reductie van de ammoniakemissie van tussen 20 à $40 \%$ te bereiken is (zie ook Monteny \& van Hoof 2020).

In het navolgende bespreken we het actief koelen van mest in de mestkelder. Dit principe zou ook in buiten opslagen toegepast kunnen worden. 
T.a.v. methaan is het doel van koeling om mest onder $10^{\circ} \mathrm{C}\left(8^{\circ} \mathrm{C}\right.$ bijvoorbeeld) te brengen. In figuur 1 zien we een toename in biogasopbrengst vanaf $10^{\circ} \mathrm{C}$, daarom blijven we het liefst onder de $10^{\circ} \mathrm{C}$. We houden even $8^{\circ} \mathrm{C}$ aan voor de zekerheid

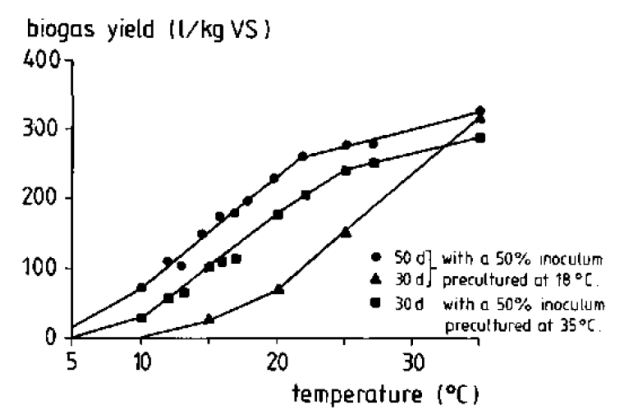

Figuur 1

Effect van mesttemperatuur op de (biogas en dus de) methaanproductie (Zeeman, 1991).

Er zijn verschillende technieken die toegepast kunnen worden om warmte aan mest te onttrekken.

1. Lamellen. Smits en collega's (Smits et al., 2005) rapporteren bijvoorbeeld dat de ammoniakemissie beperkt kan worden door de laag mest boven in het mestkanaal te koelen met behulp van drijvende koelelementen, lamellen. Door de lamellen vloeit grondwater. Het gebruik van grondwater is gebonden aan specifieke regels. Het lamellensysteem is bekend vanuit de varkenshouderij waar het rond de eeuwwisseling op redelijke schaal in bestaande stallen werd ingebouwd.
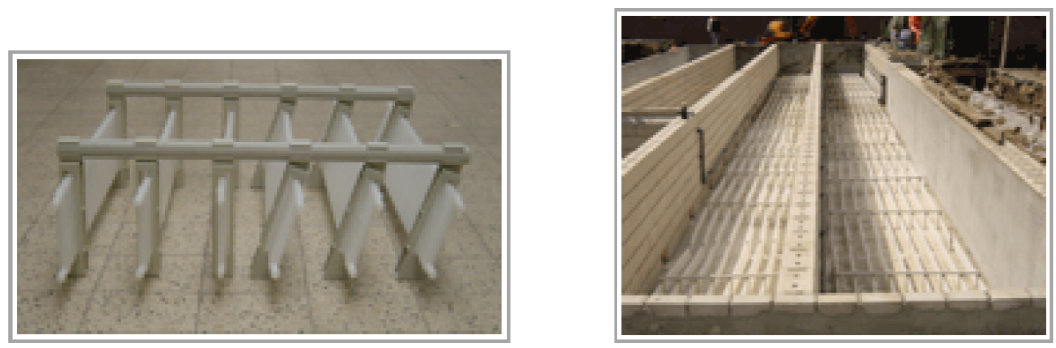

Foto links: $\quad$ zij-aanzicht van een koeldek unit

Foto rechts: bovenaanzicht van een koeldeksysteem in de mestkelder van een varkensstal in aanbouw. Zodra er voldoende mest in de mestkelder wordt opgeslagen, gaan de elementen drijven in de toplaag van de mest.

Foto 2 Impressie van het lamellen systeem voor een kalverbedrijf (Smits et al., 2005).

2. Buizensysteem. Een systeem van buizen is op de vloer en/of langs de wanden van de mestkelder geplaatst. Het buizensysteem is gevuld met vloeibaar koelmiddel (zoals water of glycol. Of een gas). De mest warmt het water/koelmiddel op en d.m.v. een warmtepomp kan die warmte aan het koelmiddel onttrokken worden en naar een hogere temperatuur opgewaardeerd in een ander medium - zie hieronder. Opslag van warm water kan in een buffervat plaatsvinden. Het afgekoelde koelmiddel gaat retour in het buizensysteem.

Dit systeem is in de ontwikkelingsfase en zijn er nog geen commerciële verkrijgbare systemen in de markt bekend. 
Om de mest homogeen te kunnen koelen moet deze met enige regelmaat worden gemixt. Hiervoor is een mixsysteem nodig. Dit kan een elektrische mestmixer (onze voorkeur) zijn of en mixer die bij de trekker aangekoppeld kan worden
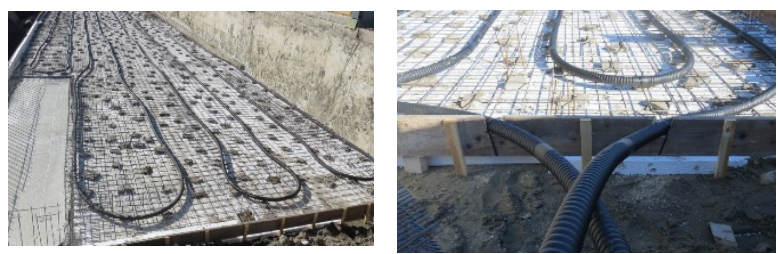

Foto 3

Impressie van een buizensysteem om mest te koelen in een melkveebedrijf. ${ }^{14}$

Bij deze systemen (buizen of lamellen) wordt tegenwoordig een warmtepomp gebruikt om warmte aan de mest te kunnen onttrekken. Bij het vroegere lamellensysteem werd opgewarmd grondwater teruggepompt de aarde in. In tegenstelling tot vroeger wordt de warmte niet geloosd via grondwater als koelmiddel, maar wordt de warmte met een warmtepomp onttrokken aan het koelmiddel, en opgeslagen. Het koelmiddel kan zo eindeloos worden hergebruikt in het proces.

De systemen kunnen worden voorzien van een interface om de koelingscapaciteit te reguleren.

De restwarmte kan benut worden om bijvoorbeeld de stal, huizen of andere gebouwen van warmte te voorzien of om activiteiten als gras-, mest-drogen etc. te kunnen uitvoeren. Indien er geen warmtevraag is, of als er een warmteoverschot is kan deze warmte ook actief geloosd worden (bijvoorbeeld in de buitenlucht), wat vaak extra energie kost en jammer van de warmte.

Momenteel wordt toepassing van lamellen om de toplaag van kalvermest te koelen in de praktijk getest. Koelen met grondwater biedt onvoldoende perspectief, omdat daarmee bij vleeskalveren te weinig verlaging van de mesttemperatuur wordt bereikt. Met een warmtepomp kan verder worden gekoeld. De eerste voorzichtige resultaten laten zien dat er een reductie van rond 20-35\% ammoniakemissie bereikt kan worden (Monteny \& van Hoof 2020), maar dat het systeem nog verder geoptimaliseerd moet worden t.a.v. de koelcapaciteit die nodig is om kalvermest te koelen (persoonlijk communicatie, juni 2020).

${ }^{14}$ www.boerderij.nl/Rundveehouderij/Achtergrond/2019/6/Melkveehouder-hergebruikt-warmte-uit-mest-en-melk-437586E/ (geraadpleegd, juni 2020). 


\subsection{Toetsingskader}

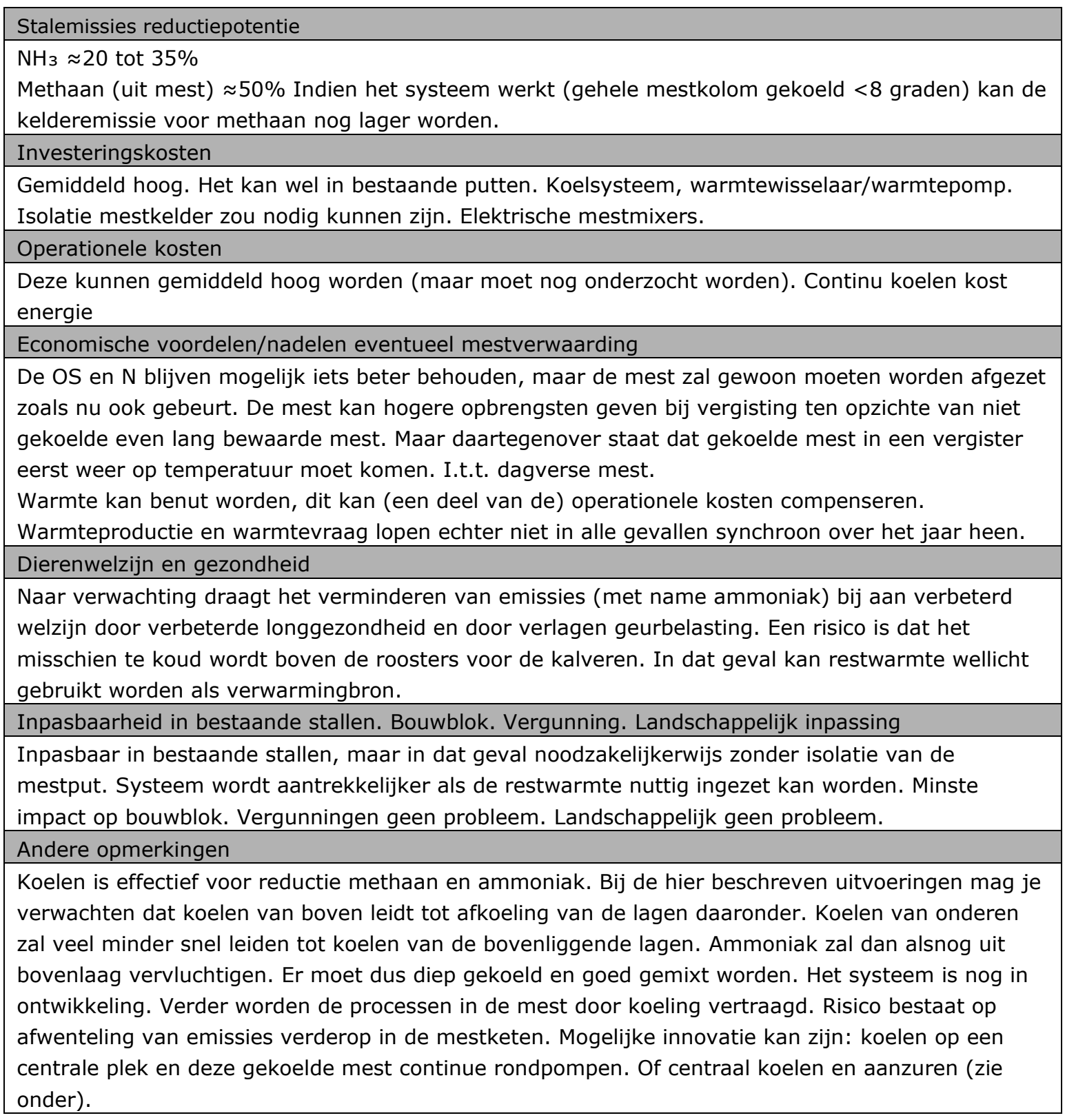




\section{$5 \quad$ Toevoegingsmiddelen - mest aanzuren}

Door specifieke middelen aan de mest toe te voegen is het mogelijk om de ammoniakemissie en methaanvorming te reduceren. Antibacteriële middelen kunnen bijvoorbeeld rechtstreeks een reducerend effect hebben op de activiteit van de methanogene microben. Martinez et al. (Martinez et al., 2003) beschrijven dat in de varkenshouderij een interessante reductie bereikt kan worden bij varkensmest met commerciële middelen als de chemische additieven NX23 (47\% methaanemissiereductie), Stalosan (54\%) en Biosusper (64\%) (Martinez et al., 2003). Deze resultaten komen echter uit een experimentele setting, waardoor het moeilijk is om de kosten en het werkelijke effect op de emissies in praktijksituaties in te schatten (Mosquera et al., 2013) en of het van invloed is op het gebruik als meststof. De werking van deze middelen op methaan zou deels gebaseerd zijn op de verlaging van de pH-waarde. Recent onderzoek in Denemarken heeft positieve resultaten opgeleverd bij experimenten met looizuur (als microbiële remmer) gecombineerd met fluoride (Gade, 2019). ${ }^{15}$

Andere additieven liggen in de sfeer van de zogenoemde 'actieve micro-organismen'. Veehouders gebruiken deze middelen meestal ten behoeve van de homogeniteit van mest. Experts zijn kritisch t.a.v. het werkelijke effect op emissies die sommige leveranciers claimen omdat het aan goede, objectieve metingen ontbreekt en er geen plausibel werkingsmechanisme kan worden genoemd. Mogelijk zijn er wel initiatieven/middelen met potentie. Tot op heden zijn er geen mestadditieven waarvan de werking (emissiereductie) is vastgesteld en die door de overheid zijn erkend.

\subsection{Mest aanzuren}

Door het toevoegen van zuren wordt de $\mathrm{pH}$ van mest verlaagd. Dit wordt gezien als een kansrijke maatregel waarmee afhankelijk van het zuur en de toegevoegde hoeveelheid, een reductie van $65 \%$ à 90\% (van de emissie uit mest) van methaan bereikt kan worden (Petersen et al., 2012; Petersen et al., 2014; Šebek et al., 2016). Recenter onderzoek (Habewold et al., 2018) met zwavelzuur $\left(\mathrm{H}_{2} \mathrm{O}_{4}\right)$

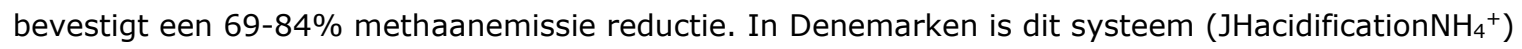
gestandaardiseerd en toegepast voor ammoniakemissie met positieve resultaten (hierna/onder staan visuele impressies ${ }^{16}$ van het systeem). Op basis van het VERA-protocol ${ }^{17}$ levert dit een reductie van $64 \%$ ammoniakemissie in de varkenshouderij. ${ }^{18}$ In Denemarken is dit systeem in werking op 75 melkveebedrijven en in 76 varkensbedrijven.

In Nederland heeft dit systeem geen voet aan de grond gekregen, o.a. door de mogelijk verdere verzuring van de grond bij intensief gebruik (Jacobsen, 2015). Maar ook omdat het systeem in Nederland qua kosten niet met de zogenoemde emissiearme vloersystemen kan concurreren.
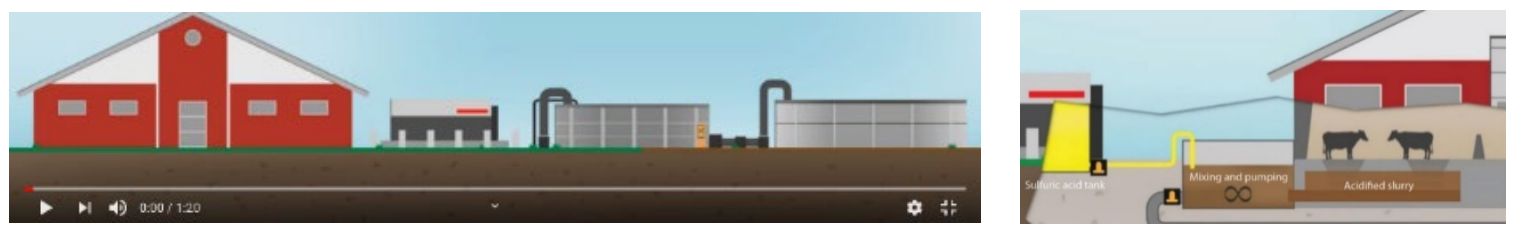

${ }^{15}$ Zie ook https://www.varkens.nl/nieuws/2020/07/23/looizuur-met-fluor-verlaagt-emissiesfors?utm_source=nieuwsbrief\&utm_medium=email\&utm_campaign=nieuwsbrief-23-07-2020 (geraadpleegd augustus 2020).

${ }^{16}$ http://jhagro.com/jh-nh4-slurry-treatment/ (geraadpleegd augustus 2020).

${ }^{17}$ VERA (Verification of Environmental Technologies for Agricultrural Production) protocol is een poging van Duitsland, Denemarken en Nederland om de meetprotocollen en informatie over milieutechnologieën in de landbouwsectoren te homogeniseren https://www.vera-verification.eu/nl/.

${ }^{18} \mathrm{http}: / /$ www.vera-verification.eu/app/uploads/sites/9/2019/05/VERA-Statement006_JH-Forsuring-NH4.pdf (geraadpleegd juli 2019) 


\section{Literatuur}

Aarnink, A. J. A., Huis in 't Veld, J., Hol, A., \& Vermeij, I. (2007). Dagelijks mestverwijderen voor beter stalklimaat en lagere emissies. $V$-focus (Oktober 2007). Retrieved from https://edepot.wur.nl/24164.

Aarnink, A. J. A., \& Puente-Rodríguez, D. (2017). Reduction of ammonia emission from areas where animals are maintained. International patent application. PCT/NL2018/050820.

Al-Haq, M.I., Sugiyama, J., \& Isobe, S. (2005). Applications of Electrolyzed Water in Agriculture \& Food Industries. Food Science and Technology Research, 11(2), 135-150. doi.org/10.3136/fstr.11.135.

Borhan, M. S., Mukhtar, S., Capareda, S., \& Rahman, S. (2012). Greenhouse Gas Emissions from Housing and Manure Management Systems at Confined Livestock Operations. In L. F. Marmolejo Rebellon (Ed.), Waste Management - An Integrated Vision (pp. 259-296): InTech. doi: 10.5772/51175

Buncic, S. \& Sofos, J. (2012). Interventions to control Salmonella contamination during poultry, cattle and pig slaughter. Food Research International, 45, 641-655. doi:10.1016/j.foodres.2011.10.018.

De Vries, J. W. (2014). From animals to crops: Environmental consequences of current and future strategies for manure management. (PhD). Wageningen University \& Research, Wageningen.

Gade, J. J. S. (2019). Indentificaiton and development of novel strategies to reduce formation of ammonia in animal manure. (PhD). University of Souther Denmark, Denmark.

GRA (2013). Reducing greenhouse gas emissions from livestock: Best practice and emerging options: Livestock Research Group (LRG) \& Global Research Alliance on Agricultural Greenhouse Gases (GRA).

Groenestein, G. M., Huijsmans, J. F. M., \& Schils, R. L. M. (2010). Emissies van broeikasgassen, ammoniak, fijn stof en geur in de mestketen. Lelystad, Wageningen Livestock Research, Rapport 248.

Groenestein, C. M., Mosquera, J., \& Van der Sluis, S.M. (2012). Emission factors for methane and nitrous oxide from manure management and mitigation options. Journal of Integrative Environmental Sciences, 9 (1), 139-146. doi: 10.1080/1943815X.2012.698990.

Groenestein, C. M., Bokma, S., \& Ogink, N. W. M. (2014). Actualisering ammoniakemissiefactoren vleeskalveren tot circa 8 maanden; Advies voor aanpassing in de Regeling ammoniak en veehouderij. Lelystad. Wageningen UR, Livestock Research, Rapport 778.

Habewold, J., Gordon, R., Sokolov, V., VanderZaag, A., Wagner-Riddle, C., \& Dunfield, K. (2018). Reduction in Methane Emissions From Acidified Dairy Slurry Is Related to Inhibition of Methanosarcina Species. Frontiers in Microbiology, 8. doi:10.3389/fmicb.2018.02806

Heeres, J., Wolthuis, M., Bokma, S., Smits, D., Stockhofe, N., Vermeij, I., \& van Reenen, K. (2017). Alternatieve vloeren voor vleeskalveren. Wageningen UR. Livestock Research, Rapport 1056.

Hoeksma, P., Oosthoek, J., Verdoes, N., \& Voermans, J. A. M. (1993). Reductie van ammoniak emissie uit varkensstallen door mestspoelen met beluchte spoelvloeistof. IMAG-DLO rapport 93-23.

Hoeksma, P., Mosquera, J., \& Melse, R. W. (2012). Monitoring methane and nitrous oxide reduction by manure treatment. Wageningen Livestock Research, Report 627).

Jacobsen, B. H. (2015). Why is acidification a success only in Denmark? A look at emission effects, costs, handling and regulation. Paper presented at the Manuresource Conference, Ghent.

Kasper, G. J., Blanken, K., \& Bokma, S. (2010). De urease-activiteit van Comfort Slat Mats in vergelijkingmet betonrooster in rundveestallen. Wageningen Livestock Research, Rapport 390.

Kroes, K., Huurman, S., de Visser, C., Hemke, G., van Liere, J., \& van den Top, N. (2016). De ECOFERM Kringloopboerderij in de praktijk. Utrecht, Innovatie Agro \& Natuur.

KWIN 2020-2021 (2020). Kwantitatieve Informatie Veehouderij 2020-2021. Wageningen Livestock Research, Handboek 43.

Martinez, J., Guiziou, F., Peu, P., \& Gueutier, V. (2003). Influence of treatment techniques for pig slurry on methane emissions during subsequent storage. Biosystems Engineering, 85(3), 347-354. doi:10.1016/S1537-5110(03)00067-9

Massé, D. I., Jarret, G., Hassanat, F., Benchaar, C., \& Cata Saady, N. M. (2016). Effect of increasing levels of corn silage in an alfalfa-based dairy cow diet and of manure management practices on manure fugitive methane emissions. Agriculture, Ecosystems and Environment, 221, 109-114. doi:10.1016/j.agee.2016.01.018.

Monteny, G-J \& van Hoof, W. (2020). Emissiearme vleeskalverstallen. Case/control-metingen aan emissiereducerende systemen voor wit-/blankvleeskalveren gedurende 2 afmestperiodes in 2018/2019 in Someren (Noord-Brabant). Monteny Milieu Advies, kei groen. Deelrapport Fase 3. file:///C:/Users/puent001/AppData/Local/Temp/Emissiearme\%20veeeskalverstallen\%20NBr_Fase\% 203 case\%20control\%20metingen\%20praktijkstal\%20Someren.pdf.

Mosquera, J., Groenestein, C. M., Timmerman, M., Aarnink, A. J. A., \& Winkel, A. (2013). Deskstudie naar maatregelen ter vermindering van broeikasgasemissies uit varkens- en pluimveestallen. Wageningen Livestock Research Rapport 750.

Mosquera, J., van Hattum, T., Nijeboer, G. M., Hol, J. M. G., van Dooren, H. J., \& Bokma, S. (2017). Effect of floor type on the ammonia and odour emission from veal calves housing. Wageningen Livestock Research, Report 980.

Mosquera, J., van Hattum, T., Nijeboer, G. M., Hol, J. M. G., van Dooren, H. J., \& Bokma, S. (2019). Ammonia and odour emission from a veal calves housing system with $V$-shaped manure belt and 'Groene Vlag' slatted floor. Wageningen Livestock Research, Report 1171.

Mukhopadhyay, S. \& Ramaswamy, R. (2012). Application of emerging technologies to control Salmonella in foods: A review. Food Research International, 25, 666-667. doi:10.1016/j.foodres.2011.05.016. 
Petersen, S. O., Andersen, A. J., \& Eriksen, J. (2012). Eff ects of Cattle Slurry Acidifi cation on Ammonia and Methane Evolution during Storage. Journal of Environmental Quality, 41(1), 88-94. doi:10.2134/jeq2011.0184.

Petersen, S. O., Hojberg, O., Poulsen, M., Schwab, C., \& Eriksen, J. (2014). Methanogenic community changes, and emissions of methane and other gases, during storage of acidified and untreated pig slurry. Journal of Applied Microbiology, 117(1), 160-172. doi:10.1111/jam.12498.

Puente-Rodríguez, D., \& Bos, A. P. (2019). Environmental Dairy Design for 2020 (EDD20): Ontwerpen voor huisvestingssystemen van melkvee met lage ammoniakemissie. Wageningen Livestock Research, Rapport 1162.

Sakurai,Y., Ogoshi,K., Kaku,M. \& Kobayashi,I. (2002). Strongly acidic electrolyzed water: Valuable disinfectant of endoscopes. Digestive Endoscopy, 15: 19-24.

Šebek, L. B., Mosquera, J., \& Bannink, A. (2016). Rekenregels voor de enterische methaanemissie op het melkveebedrijf en reductie van de methaanemissie via mest-handling; het handelingsperspectief van het voerspoor inzichtelijk maken met de Kringloopwijzer. Wageningen Livestock Research, Rapport 976.

Smits, M. C. J., Melse, R. W., Smits, A. C., \& Ogink, N. W. M. (2005). Bouwsteen stallen. Quick scan van opties voor vermindering van ammoniak- en geuremissie uit vleeskalverstallen in de Agrarische Enclave Uddel Elspeet . Agrotechnology \& Food Innovations B.V. Wageningen UR, Rapport 509.

Van de Sande-Schellekens, A. L. P., van Brakel, C. E. P., \& Backus, G.B.C. (1995). Ervaringen met de Haglando-mestschuif op een vleesvarkensbedrijf in PROPRO. Praktijkonderzoek Varkenshouderij, Proefstation voor de Varkenshouderij, Rosmalen, P 1.130.

Van den Hoorn, C. J., Blanken, K., \& Gunnink, H. (2009). Oriënterende emissiemetingen aan de Comfort Slat Mats voor melkvee. Animal Sciences Group van Wageningen UR, Rapport 225.

Van Dooren, H.J.C. \& Mosquera, J. (2016). Maatregelen ter vermindering van de ammoniakemissie uit de melkveehouderij: indicatieve beoordelingen van vloer- en keldermaatregelen. Wageningen Livestock Research. Rapport 915.

Willeghems, G., De Clercq, L., Michels, E., Meers, E., \& Buysse, J. (2016). Can spatial reallocation of livestock reduce the impact of GHG emissions? Agricultural Systems, 149, 11-19. doi:10.1016/j.agsy.2016.08.006.

Zeeman, G. (1991). Mesophilic and psychrophilic digestion of liquid manure. (PhD). Landbouwuiniversiteit Wageningen, Wageningen. Retrieved from https://edepot.wur.nl/202851.

Visuals: Jochem Galama. http://new.contour-ids.nl/

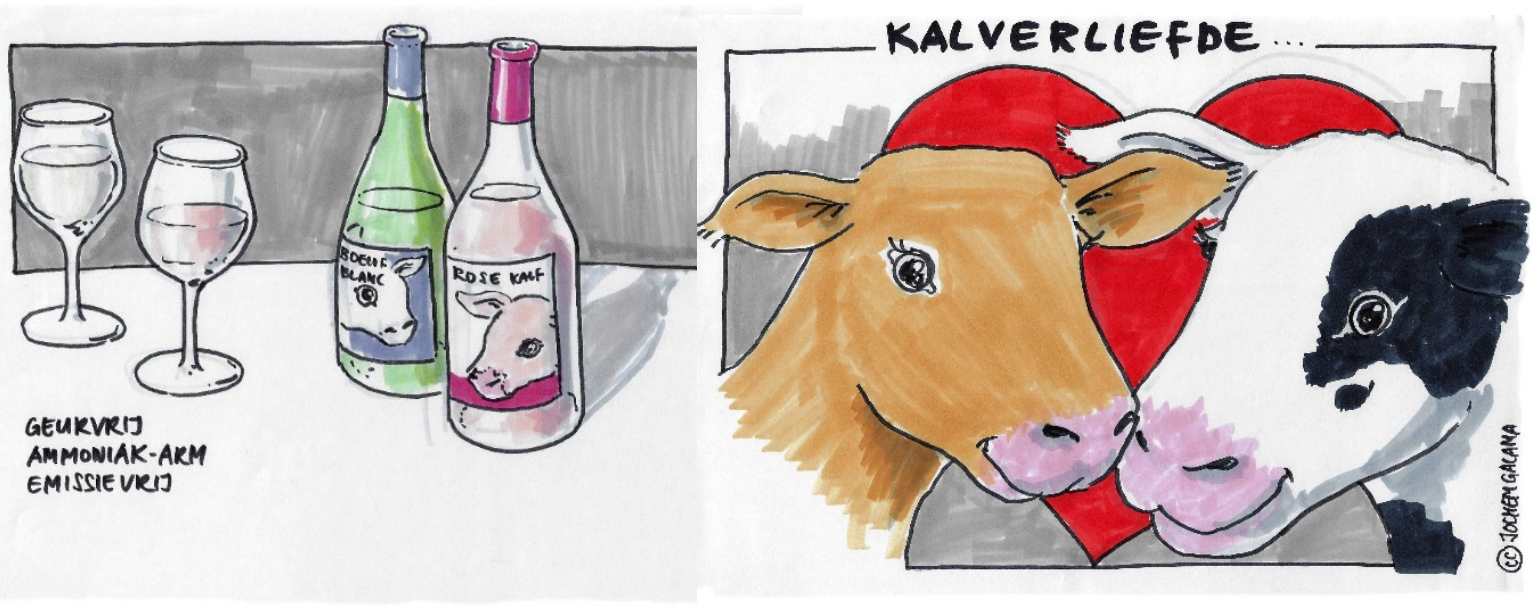



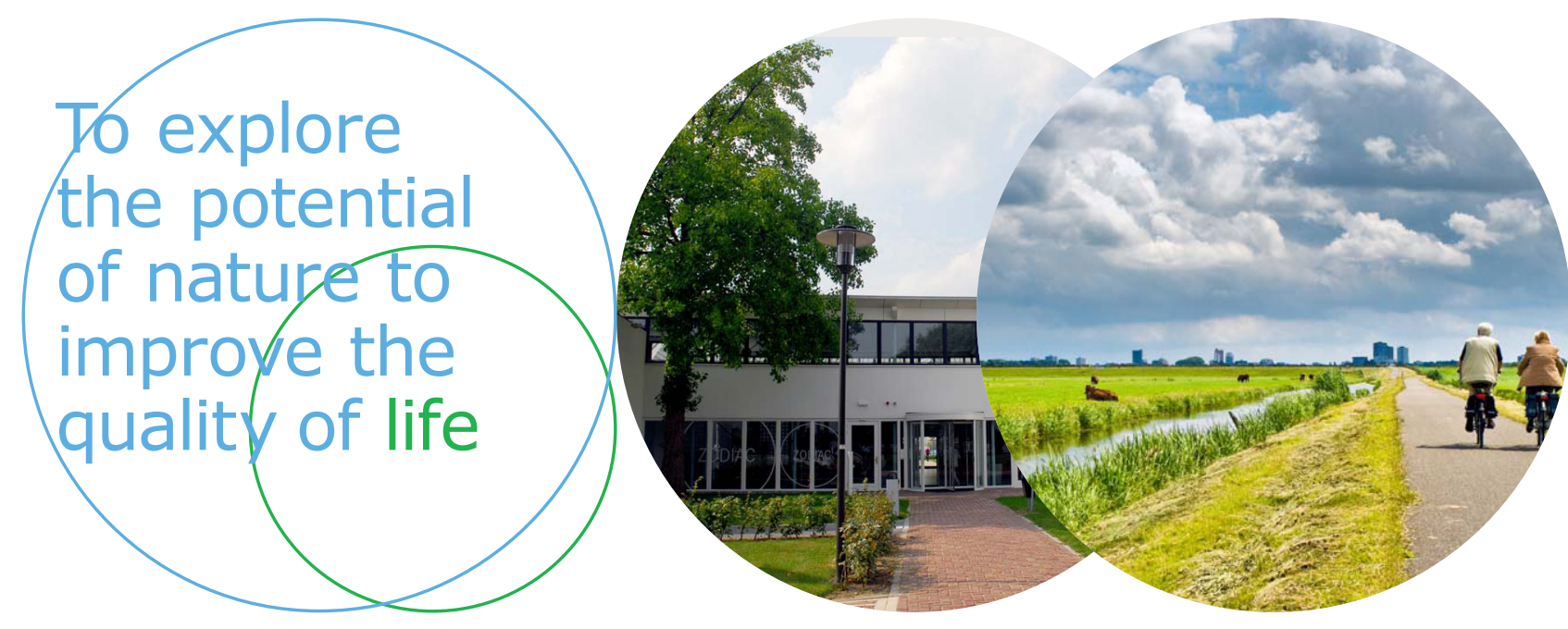

Wageningen Livestock Research Postbus 338

$6700 \mathrm{AH}$ Wageningen

T 0317483953

E info.livestockresearch@wur.nl www.wur.nl/livestock-research
Wageningen Livestock Research ontwikkelt kennis voor een zorgvuldige en renderende veehouderij, vertaalt deze naar praktijkgerichte oplossingen en innovaties, en zorgt voor doorstroming van deze kennis. Onze wetenschappelijke kennis op het gebied van veehouderijsystemen en van voeding, genetica, welzijn en milieu-impact van landbouwhuisdieren integreren we, samen met onze klanten, tot veehouderijconcepten voor de $21 \mathrm{e}$ eeuw.

De missie van Wageningen University \& Research is 'To explore the potential of nature to improve the quality of life'. Binnen Wageningen University \& Research bundelen 9 gespecialiseerde onderzoeksinstituten van Stichting Wageningen Research en Wageningen University hun krachten om bij te dragen aan de oplossing van belangrijke vragen in het domein van gezonde voeding en leefomgeving. Met ongeveer 30 vestigingen, 6.500 medewerkers en 10.000 studenten behoort Wageningen University \& Research wereldwijd tot de aansprekende kennisinstellingen binnen haar domein. De integrale benadering van de vraagstukken en de samenwerking tussen verschillende disciplines vormen het hart van de unieke Wageningen aanpak. 